\title{
Analysis of Students' Mathematical Communication Ability Based on Mathematical Resilience during the Covid-19 Pandemic
}

\author{
Afroh Mahfudoh Al'atif ${ }^{1}$, Nanang Priatna ${ }^{2}$, Yaya Sukjaya Kusumah ${ }^{3}$, Suhendra $^{4}$ \\ \{afrohalatif@upi.edu¹, nanang_priatna@upi.edu², yayaskusumah@yahoo.com ${ }^{3}$ \} \\ Mathematics Education Study Program, School of Postgraduate, Universitas Pendidikan Indonesia, Jl. \\ Dr. Setiabudi No. 229, Bandung 40154, Indonesia ${ }^{1}$ \\ Mathematics Education Department, School of Postgraduate, Universitas Pendidikan Indonesia, Jl. \\ Dr. Setiabudi No. 229, Bandung 40154, Indonesia ${ }^{2,3}$
}

\begin{abstract}
Students are faced with new global learning challenges in the Covid-19 pandemic. Likewise, education in this global era has transitioned to $21^{\text {st }}$-century skills, one of the $21^{\text {st }}$-century skills that students must be possessed, namely mathematical communication ability. Mathematical communication ability is influenced by several factors, such as students' psychological aspects. One of those psychological aspects is mathematical resilience. This study aims to describe students' mathematical communication ability based on mathematical resilience in a Covid-19 pandemic due to pandemic. Based on the study objectives, this study used descriptive qualitative research. Data collection techniques used test of mathematical communication ability, questionnaire of mathematical resilience, and interview. The results showed that the students' mathematical communication ability was quite good, based on students' mathematical resilience. Still, there were some difficulties that students experienced due to limited learning during the Covid-19 pandemic.
\end{abstract}

Keywords: Mathematical Communication Ability, Mathematical Resilience, Covid-19 Pandemic

\section{Introduction}

Since the beginning of 2020, Covid-19 reports have been taking place worldwide, especially in Indonesia. This Covid-19 case was initially suspected of pneumonia with the first appearance from Wuhan province, China [1][2]. Covid-19 is caused by acute respiratory syndrome coronavirus 2 (Severe Acute Respiratory Syndrome Coronavirus 2 or SARSCov-2) and infectious disease [3][4]. Because it is contagious, it is feared that it will spread rapidly if there is frequent and direct social interaction, so the government has suggested a condition where everyone should keep their distance from each other and not interact with each other.

The Covid-19 pandemic has changed almost all areas of life throughout the world, one of which is in education, and the Indonesian state is none other than participating in this change [5]. This pandemic has made educational activities change drastically, where the learning period in both schools and colleges has shifted from face-to-face learning to online learning. The government decided to close schools and colleges. Face-to-face meetings were also eliminated to minimize the spread of Covid-19. This is indeed surprising for most educators and parents, 
even though the government and school principals have been wary of news of the Covid-19 virus from outside China. So that a consequence, the government and related institutions at least look for alternative ways to continue learning during the pandemic with the creation of a distance learning curriculum [6].

Students face new global learning challenges during the Covid-19 pandemic, especially in mathematics learning, where they learn by applying online learning methods at home. Mathematics learning, which is usually done directly in schools through teacher explanations using PowerPoint or blackboard, has now turned into online learning. This learning is still considered unusual for students because it is done through online platform such as Edmodo, Zoom, Google Classroom, or other online learning platform. This becomes a challenge for students to work harder in understanding mathematics learning material because many students are still not trained in online learning platform and still confused by the material explanation in the form of video learning [7]. With new global learning challenges, students can benefit from studying at home, spending time with family, and avoiding the Covid-19 virus. However, on the other hand, it also harms students, they tend to be bored and lazy with the homework given by their teacher, want to go to school immediately, and most students feel unhappy with distance learning [8]. This dramatically affects learning mathematics. They tend to be lazy and complain when given consecutive assignments, lack understanding of the learning material, and obtained, especially in pictures.

Besides being faced with distance learning methods, students have also entered a global era transitioning to $21^{\text {st }}$-century skills. As explained in $21^{\text {st }}$-century skills, students must have four competencies called $4 \mathrm{C}$, one of which is mathematical communication ability. Lomibao revealed that mathematical communication ability allows students to express their ideas, describe, and explain mathematical concepts coherently and clearly [9]. With mathematical communication ability, students are challenged to communicate their ideas both in writing and orally to friends, teachers, or others so that it will encourage students to think and reason so that their ideas are expressed through writing, diagrams, tables, pictures, algebraic, as well as verbal. Using the correct mathematical language to speak and write about what they do, they will be able to clarify their ideas and learn how to make convincing arguments and present mathematical ideas [10][11].

Students can be said to have good mathematical communication ability if they can meet mathematical communication ability indicators. Mathematical communication indicators are several mathematical activities; according to Sumarmo, the details of indicators include: connecting real objects, pictures, and diagrams into mathematical ideas; explain mathematical ideas verbally with pictures; express everyday events in mathematical symbols; listening, discussing and, writing about mathematics; read with the understanding of a written presentation and make conjectures, construct arguments, formulate definitions and generalizations [12]. Mathematical communication ability is influenced by various factors, such as students' psychological aspects in the learning process. One of the psychological aspects is mathematical resilience. Some students still feel anxious about learning mathematics and the situation during this pandemic, which can make it difficult for students to ask questions directly due to limited time in learning. Mathematical resilience is a positive attitude to overcome anxiety, fear in facing challenges and difficulties in learning mathematics, including hard work and good language skills, self-confidence, and diligence in facing difficulties [13]. Students who have good mathematical resilience think that learning mathematics is not an obstacle. Even when students experience difficulties, they will maintain their confidence until success [14].

In delivering mathematical communication, it is necessary to have a positive attitude in dealing with anxiety and fear when students give different answers. Because without this 
positive attitude, students will feel anxious if the delivery of the answers they give is wrong, so students prefer not to express their ideas and prefer to be silent. Rahmatiyya argues that students often feel uncomfortable, tense, or do not like learning mathematics, especially in working on difficult questions; they tend not to ask their teachers or friends [15]. Moreover, because of this online learning, students' comfort in learning is essential because interaction with the teacher is quite limited, so they must handle their mathematical resilience and mathematical communication ability.

Based on the explanation above, the purpose of this study is to describe students' mathematical communication ability based on mathematical resilience during the Covid-19 pandemic.

\section{Method}

The descriptive qualitative analysis approach is the methodology used in this study. The study began with making an instrument in the form of a mathematical communication test consisting of three essay questions, a mathematical resilience questionnaire containing 30 statements and distributed online, and interviews conducted via Zoom. Seven students of $10^{\text {th }}$ grade high school were given a mathematical communication ability instrument test for data collection and continued by filling out a mathematical resilience questionnaire. After giving the test and non-test instruments, students were interviewed via Zoom regarding the difficulty of the questions they had worked on to strengthen their test and questionnaire results.

The mathematical resilience questionnaire was adapted from (Maesaroh \& Sumarmo, 2019) with the following indicators: (1) perseverance, confidence, working hard, not easily giving up in facing problems, failures, and uncertainties; (2) willingness to socialize, easy to assist, discuss with peers, and adapt to their environment; (3) showing curiosity, reflecting, researching, utilizing various sources; (4) having language skills, self-control and be aware of their feelings; (5) using the experience of failure to build self-motivation [16]. However, out of 34 statements on the questionnaire adapted, only 30 statements were used as non-test instruments. Each statement from the mathematical resilience questionnaire has four answer options, namely strongly agree (SS), agree (S), disagree (TS), and strongly disagree (STS). After being tested, the questionnaire results were analyzed to determine which students had high, medium, and low resilience. The step of categorizing the resilience questionnaire in the study is looking for the lowest and highest values, looking for the ideal mean $(\mathrm{M})$, which is $1 / 2$ (highest value + lowest value), and looking for the standard deviation (SD), which is $1 / 6$ (highest value - lowest value) [17]. Based on these steps, calculations are carried out, as shown in Figure 1 and Table 1.

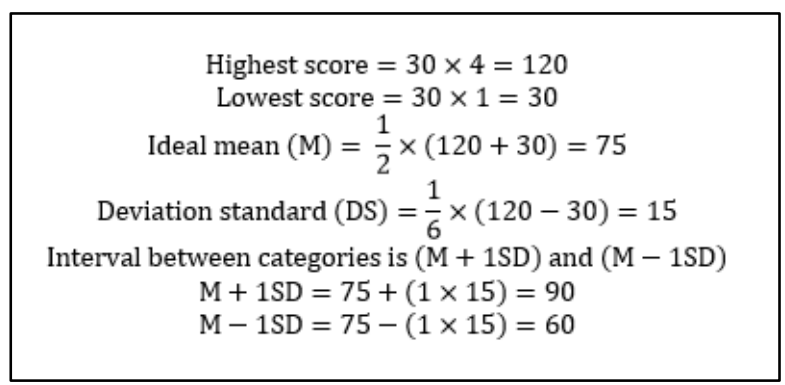


Fig. 1. The calculation to determine the intervals of mathematical resilience

Table 1. Interval of mathematical resilience.

\begin{tabular}{ccc}
\hline Interval & Interval & Category \\
\hline $\mathrm{X}<\mathrm{M}-1 \mathrm{SD}$ & $\mathrm{X}<60$ & Low Resilience \\
$\mathrm{M}-1 \mathrm{SD} \leq \mathrm{X}<\mathrm{M}+1 \mathrm{SD}$ & $60 \leq \mathrm{X}<90$ & Medium Resilience \\
$\mathrm{X} \geq \mathrm{M}+1 \mathrm{SD}$ & $\mathrm{X} \geq 90$ & High Resilience \\
\hline
\end{tabular}

The results of mathematical communication tests were analyzed by calculating the percentage, as shown in [18] in Table 2.

Table 2. Categorization of mathematical communication

\begin{tabular}{ccc}
\hline Score & Level of ability & Category \\
\hline $0-34$ & $0 \%-34 \%$ & Very Low \\
$35-54$ & $35 \%-54 \%$ & Low \\
$55-64$ & $55 \%-64 \%$ & Medium \\
$65-84$ & $65 \%-84 \%$ & High \\
$85-100$ & $85 \%-100 \%$ & Very High \\
\hline
\end{tabular}

Mathematical communication ability test questions and indicators of mathematical communication ability are shown in Table 3.

Table 3. Indicators and questions test of mathematical communication ability

\footnotetext{
Indicators of mathematical communication

Express real objects, situations, and everyday events into mathematical models (pictures, tables, diagrams, graphs, algebraic expressions); Explain mathematical ideas and models (pictures, tables, diagrams, graphs, algebraic expressions) and solve them

Expressing real objects, situations, 2 and everyday events in the form of mathematical models (pictures, tables, diagrams, graphs, algebraic expressions); Declare everyday events in language or mathematical symbols and solve them
}

Problem

. Given the perimeter of the triangle $P Q R 70 \mathrm{~cm}$. The $P R$ length is $2 \mathrm{~cm}$ more than the PQ length. QR length is $6 \mathrm{~cm}$ less than $P R$ length. If $x$ represents the length of $P Q$, y represents the length of $\mathrm{QR}$, and $\mathrm{z}$ represents the length of $\mathrm{PR}$.

a. Create a mathematical model for the side-length relationships of triangle $\mathrm{ABC}$.

b. Calculate how long each side of triangle $\mathrm{ABC}$ is.

2. An isolated metal rod with a temperature at each point is indicated by $\mathrm{t}_{1}, \mathrm{t}_{2}, \mathrm{t}_{3}$, as shown in the figure.

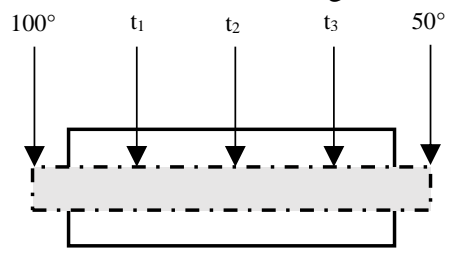

If the temperature at the designated points is equal to the average of the two temperatures at the nearest point, what is the temperature at $\mathrm{t}_{1}$ ? Arrange a proper mathematical model and solve the problem. 
Stating situations of everyday events into tabular form, constructing mathematical models of problems and solving them.
3. Pak Arief has three hectares of rice fields planted with rice, and it is time for fertilizer. Three types of fertilizers must be provided, namely Urea, SS, TSP. Farmers must use these three types of fertilizers for maximum rice yields. The price for each bag of fertilizer is 60,000 IDR; 125,000 IDR; and 145,000 IDR. Pak Arief needs as many as 60 sacks for rice fields planted with rice. The use of SS fertilizer is three times as much as TSP fertilizer. Meanwhile, the funds provided by Pak Arief to buy fertilizer is 5,000,000 IDR. How many sacks for each type of fertilizer should Mr. Arief buy?

\section{Result and Discussion}

The data obtained in this study came from tests of mathematical communication ability, mathematical resilience questionnaires, which were distributed online, and also interviews via Zoom. Based on the study that has been done, the seven students' mathematical resilience categories can be seen in Table 4.

Table 4. The Result of Mathematical Resilience Questionnaires

\begin{tabular}{ccc}
\hline $\begin{array}{c}\text { Mathematical Resilience } \\
\text { Categories }\end{array}$ & Students' Codes & Number of students \\
\hline High & S1, S4, S7 & 3 \\
Medium & S2, S3 & 2 \\
Low & S5, S6 & 2 \\
\hline
\end{tabular}

Table 4 shows that of the seven students, two students have low mathematical resilience, and three have high mathematical resilience. Furthermore, the students' mathematical resilience data were compared with the students' mathematical communication ability test results.

Table 5. The Result of Mathematical Communication Ability Based on Resilience Category

\begin{tabular}{cccc}
\hline Resilience Category & Students' Codes & $\begin{array}{c}\text { Mathematical } \\
\text { Communication Score }\end{array}$ & $\begin{array}{c}\text { Percentage of Mathematical } \\
\text { Communication }\end{array}$ \\
\hline High & S1 & 80 & $80 \%$ \\
& S4 & 75 & $75 \%$ \\
Medium & S7 & 85 & $85 \%$ \\
& S2 & 60 & $60 \%$ \\
Low & S3 & 50 & $50 \%$ \\
& S5 & 40 & $40 \%$ \\
& S6 & 25 & $25 \%$ \\
\hline
\end{tabular}

Table 5 shows that $\mathrm{S} 1, \mathrm{~S} 4$, and $\mathrm{S} 7$, who have high mathematical resilience, are in the same category in mathematical communication ability, with the respective percentages being $80 \%$, $75 \%$, and $85 \%$. S1 and S2 students are in the 65\%-84\% interval with the high category, and S3 are at the $85 \%-100 \%$ interval with the category of very high mathematical communication ability; S2 has moderate mathematical resilience and is in the same category as their mathematical communication ability which is in the moderate category with a percentage of 
$60 \%$. Meanwhile, S3 has moderate mathematical resilience, but the ability to communicate mathematics is low, with a percentage of $50 \%$. S5 and S6 both have low mathematical resilience and low mathematical communication capabilities. However, S6's mathematical communication ability is lower than S5, with a communication ability percentage of $25 \%$.

Table 5 shows that students with high mathematical resilience obtain high and very high scores of mathematical communication ability. Meanwhile, students with low mathematical resilience obtain low and very low scores of communication ability.

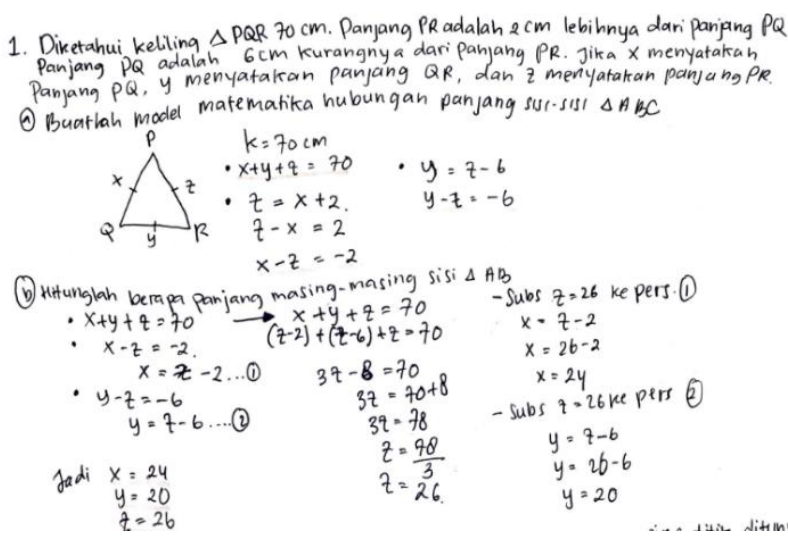

Fig. 2. Solution number 1 by a student (S4) with high mathematical resilience

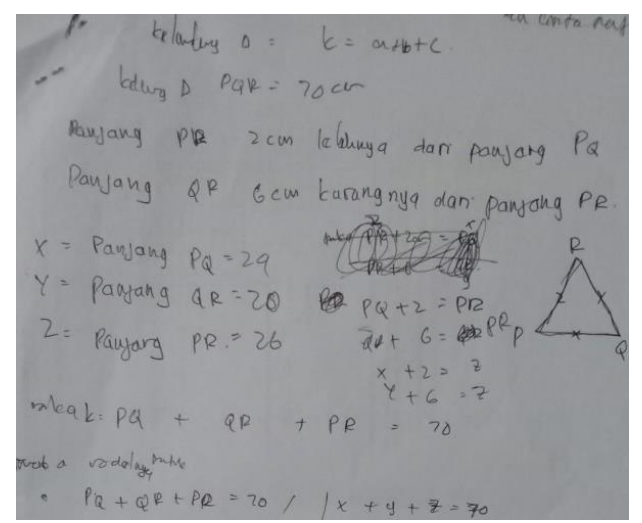

Fig. 3. Solution number 1 by a student (S6) with low mathematical resiliences

Figure 2 shows that students (S4) with high mathematical resilience can express problems/ideas in the form of images, state situations in a mathematical model, explain the relationship between variables well and solve problems. In Figure 3, students (S6) with low mathematical resilience cannot explain their answers well in a mathematical model. The answers they give are correct but not systematic; language delivery in mathematical ideas and mathematical symbols still has many shortcomings. Whereas in Figure 4, the student's (S3) answer with moderate resilience is right; he can state the situation in the form of a mathematical model and solve it well.

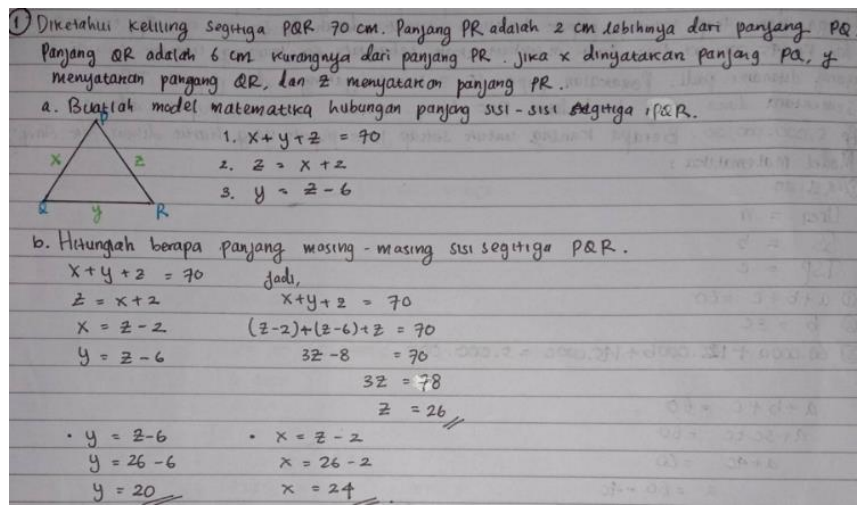

Fig. 4. Solution number 1 by a student (S3) with medium mathematical resilience 
Figures 5, 6, 7 show the answers to the second problem solving of each student with moderate (S2), low (S5), and high (S4) mathematical resilience. Figure 5 shows that students with moderate mathematical resilience (S2) can state an event in the form of a mathematical model even though the procedure in progress and the answer is not correct. Not much different from S2 students, in Figure 6, students with low mathematical resilience (S5) can express an event in the form of a mathematical model but cannot solve it well. Both students' answers were wrong in their solution. Although they can write problems into a mathematical model, there are errors in explaining mathematical relationships verbally in written form. Whereas in Figure 7, students with high mathematical resilience (S4) students can express problems into mathematical ideas with correct and systematic procedures. S4 students can explain and make relationships between variables in mathematical models and can solve problems appropriately and correctly.

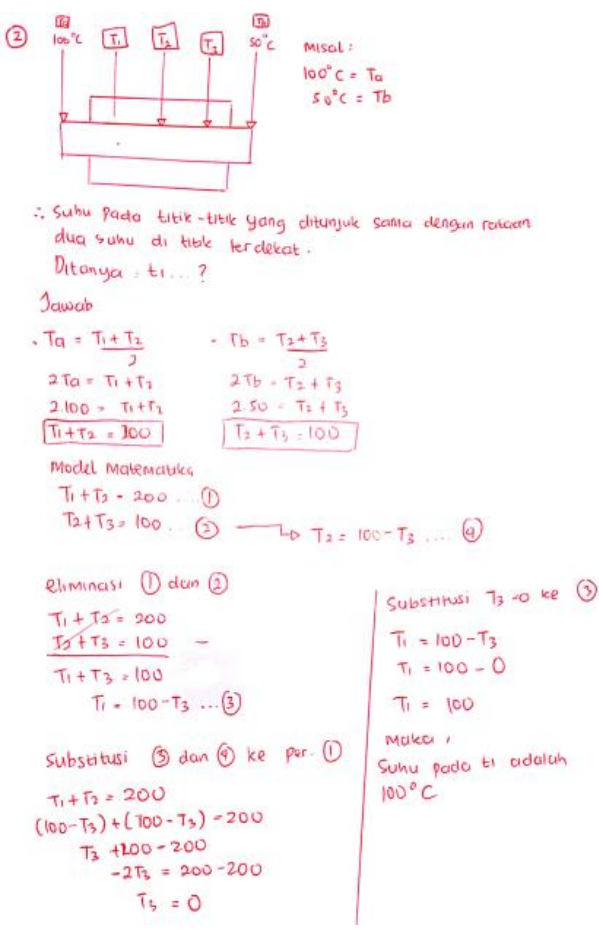

Fig. 5. Solution number 2 by a student (S2) with medium mathematical resilience

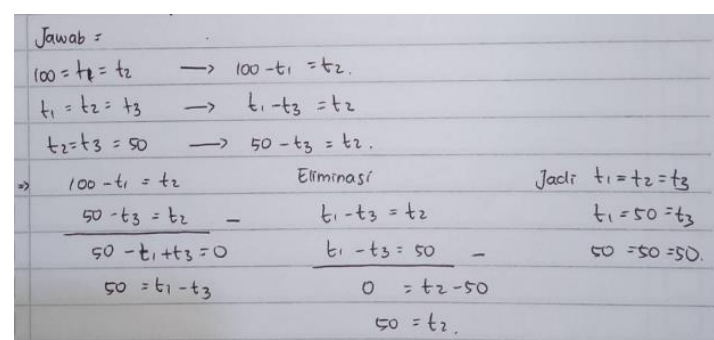

Fig. 6. Solution number 2 by a student (S5) with low mathematical resilience

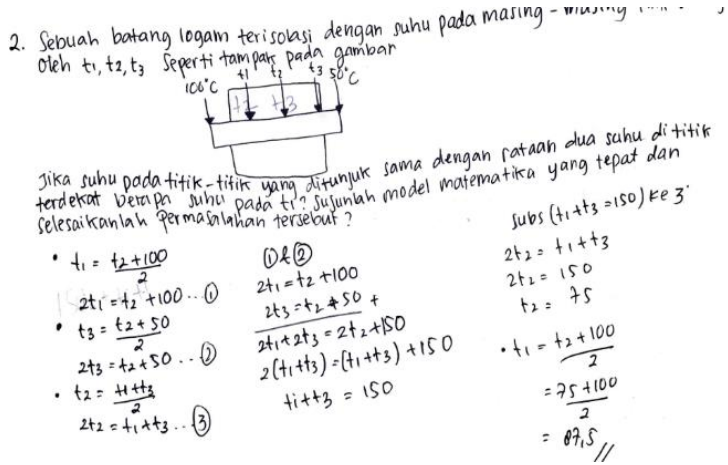

Fig. 7. Solution number 2 by a student (S4) with high mathematical resilience

Based on the student interview results after working on the questions and filling out the mathematical resilience questionnaire, they said that their working on it was quite tricky. The difficulties they experienced in learning mathematics during the Covid-19 pandemic included that sometimes the teacher provided exercises or question material that was different from the assignment questions given, so the assignments given were not the same as the exercises are done. 


\section{Conclusion}

Based on the results and discussion above, the study shows that high resilience students also have high mathematical communication ability. Some students could not solve the test questions well, but several others proved that they had good mathematical communication ability with high mathematical resilience. According to students, the Covid-19 pandemic is quite an obstacle for those who have low mathematical resilience. This is due to several factors, including the limited time to ask the teacher, the difficulty of communicating with other friends, they are not used to speaking or giving opinions in front of friends or teachers, a sense of selfdoubt, and lack of learning ability because they feel they are not in the same class state. So that it can affect students' mathematical communication ability, however, from the results of the study, it can be concluded that students' mathematical communication ability is quite good when viewed from the mathematical resilience during the Covid-19 pandemic, even though there are some difficulties they experience.

Acknowledgment. Thank you to the seven students who participated in this study to be carried out.

\section{References}

[1] Mona N. Konsep Isolasi Dalam Jaringan Sosial Untuk Meminimalisasi Efek Contagious (Kasus Penyebaran Virus Corona Di Indonesia). J Sos Hum Terap. 2020;2(2):117-25.

[2] Zu ZY, Di Jiang M, Xu PP, Chen W, Ni QQ, Lu GM, et al. Coronavirus Disease 2019 (COVID-19): A Perspective from China. Vol. 296, Radiology. 2020.

[3] Dwi B, Amelia A, Hasanah U, Putra AM, Rahman H. Analisis Keefektifan Pembelajaran Online di Masa Pandemi Covid-19. J Pendidik Guru Sekol Dasar. 2020;2(1):28-37.

[4] Harapan H, Itoh N, Yufika A, Winardi W, Keam S, Te H, et al. Coronavirus disease 2019 (COVID19): A literature review. Vol. 13, Journal of Infection and Public Health. 2020.

[5] Rasmitadila, Aliyyah RR, Rachmadtullah R, Samsudin A, Syaodih E, Nurtanto M, et al. The perceptions of primary school teachers of online learning during the COVID-19 pandemic period: A Case study in Indonesia. J Ethn Cult Stud. 2020;7(2):90-109.

[6] Putri RS, Purwanto A, Pramono R, Asbari M, Wijayanti LM, Hyun CC. Impact of the COVID-19 pandemic on online home learning: An explorative study of primary schools in Indonesia. Int J Adv Sci Technol. 2020;29(5):4809-18.

[7] Irfan M, Kusumaningrum B, Yulia Y, Widodo SA. Challenges During the Pandemic: Use of ELearning in Mathematics Learning in Higher Education. Infin J. 2020;9(2):147.

[8] Purwanto A, Pramono R, Asbari M, Santoso PB, Wijayanti LM, Hyun CC, et al. Studi Eksploratif Dampak Pandemi COVID-19 Terhadap Proses Pembelajaran Online di Sekolah Dasar. EduPsyCouns J Educ Psychol Couns [Internet]. 2020;2(1):1-12. Available from: https://ummaspul.e-journal.id/Edupsycouns/article/view/397

[9] Lomibao LS, Luna CA, Namoco RA. The Influence of Mathematical Communication on Students' Mathematics Performance and Anxiety. Am J Educ Res [Internet]. 2016;4(5):378-82. Available from: http://pubs.sciepub.com/education/4/5/3

[10] Hutami EW, Sari LU, Vitasari RN, Wicaksono B. Identifikasi Indikator Kemampuan Komunikasi Matematis pada Soal USBN Matematika SD / MI Tahun Ajaran 2018 / 2019. J Ilm Pendidik Mat. 2019;7(2):1-10.

[11] Harianja JK, Hernadi SL, Indah I. Learner's Mathematical Conceptual Understanding and Its Relation to The Mathematical Communication Skills. JP3M (Jurnal Penelit Pendidik dan Pengajaran Mat. 2020;6(1):1-12.

[12] Sumarmo U. Pendidikan karakter serta pengembangan berfikir dan disposisi matematik dalam 
pembelajaran matematika. Semin Pendidik Mat. 2012;

[13] Johnston-Wilder S, Lee C. Developing Mathematical Resilience. BERA Annu Conf Univ Warwick. 2010; Vol. 4(2).

[14] Asih KS, Isnarto, Sukestiyarno, Wardono. Resiliensi Matematis pada Pembelajaran Discovery Learning dalam Upaya Meningkatkan Komunikasi Matematika. Prism Pros Semin Nas Mat. 2019;2:862-8.

[15] Rahmatiyya R, Miatun A. Analisis Kemampuan Pemecahan Masalah Matematis Ditinjau dari Disposisi Matematis Siswa SMP. TeoremaTeori dan Ris Mat. 2020;5(2):187-202.

[16] Sumarmo U, Hendriana H, Ahmad, Yuliani A. Tes dan Skala Matematika Bernuansa High Order Thinking Skills. 2019.

[17] Ulfa WD. Resiliensi pada Mahasiswa yang Memiliki Orangtua Tunggal. J Bimbing dan Konseling. 2016;5(5).

[18] Thalhah SZ. Peningkatan Kemampuan Komunikasi Matematika Melalui Pembelajaran dengan Pendekatan Problem Posing Pada Siswa Kelas X6 MAN Pinrang. MaPan J Mat dan Pembelajaran. 2014;2(1):86-104. 